\title{
Mechanical and electro-mechanical box cochlea model
}

\author{
M. Nikolic ${ }^{1,2}$, V. Isailovic ${ }^{1,2}$, D. Nikolic ${ }^{1,2}$, I. Saveljic ${ }^{1,2}$, Z. Milosevic ${ }^{1,2}$, M. Radovic ${ }^{1,2}$, \\ S.Semmelbauer $^{3}$, F. Bohnke ${ }^{3}$ and N. Filipovic ${ }^{1,2^{*}}$ \\ ${ }^{1}$ Faculty of Engineering, University of Kragujevac, Kragujevac, Serbia \\ obradovicm@kg.ac.rs \\ ${ }^{2}$ Bioengineering R\&D Center Kragujevac, Kragujevac, Serbia \\ ${ }^{3}$ Department of Otorhinolaryngology, Technical University Munich, Munich, Germany \\ * Corresponding author
}

\begin{abstract}
The cochlea is the most important part of the hearing system, due to the fact that it receives sound in the form of vibrations and converts these vibrations into nerve impulses in the organ of Corti that sends information about sounds to the brain. Functioning of the cochlea components and behavior is still not investigated completely because of its complex structure. Human live cochlea is placed in almost inaccessible place. Because of that it is hard to collect experimental measurement. Cochlea works as an electro-mechanical system and it is important to investigate both electrical and mechanical behavior of the cochlea in order to improve treatment of hearing disorders. This study presents a mechanical model of the uncoiled cochlea using full 3D 8-noded finite elements, as well the electro-mechanical 1D state-space model of the cochlea. The results obtained from these two cochlea models show good matching with Greenwood function and properly simulate the behavior of the cochlea.
\end{abstract}

Keywords: cochlea, finite element method, state-space model

\section{Introduction}

Ear consists of external, middle and inner part. Functioning of the hearing system depends on inner ear, where cochlea is placed. The cochlea is part of the inner ear and it has shape like a snail. It is divided into three chambers (scala vestibuli, scala media and scala tympani), filled with fluid (endolymh and perilymph) and separated by membranes-basilar membrane and Reissner's membrane (Fig. 1).

Input signal comes from the stapes and then the sound travels through the fluid causing vibrations of the basilar membrane and motion of the organ of Corti. Then there is a conversion of mechanical energy into electrical energy, generation of current and change in electrical potential.

The electrical part of the cochlea serves to amplify sounds and innervate nerves which send information to the brain. Since the organ of Corti amplifies the input signal, human cochlea can distinguish sounds in the range of $16 \mathrm{~Hz}-20 \mathrm{kHz}$. Steele (Steele (1987)) and Nobili (Nobili et al (1998)) gave detailed summary of analysis and data related to macro-mechanical aspect and surveys up to 1982 and opened a new area for research of the human hearing system. 


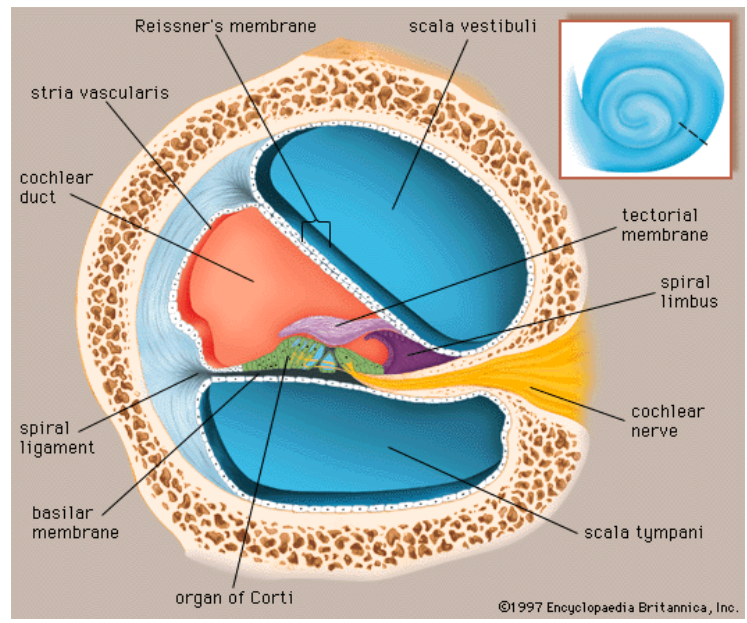

Fig. 1. - Anatomy of the cochlea ${ }^{1}$

In case when only mechanical behavior of the cochlea is analyzed and modelled, a middle fluid chamber (scala media) can be neglected, since it does not significantly affect motion of the basilar membrane. The model consists of the scala vestibuli and scala tympani, separated by the basilar membrane. The simplest model of the cochlea is a box model of the uncoiled cochlea. The coiling has not large influence on behavior of the cochlea and therefore most of the cochlea models are uncoiled because of the simpler geometry and computational efficiency. The mechanical model of the cochlea was created using finite element method with full 3D elements (Fig. 2) and solved in PAK solver (Kojic et al. (2009)). Theoretical background for the model includes acoustic wave equation, for describing behavior of the fluid in chambers, and Newtonian dynamic equation, for describing the motion of the basilar membrane.
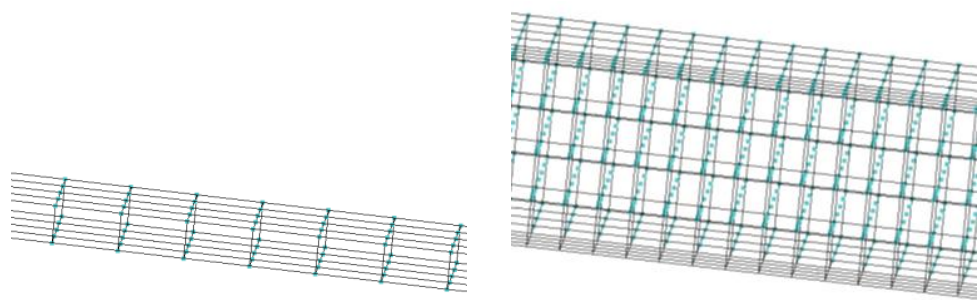

Fig. 2. - Solid (left) and fluid (right) full 3D 8-noded elements.

When the electrical model of cochlea is analyzed, the scala media cannot be neglected. The organ of Corti is placed inside the scala media and its structure is presented in Fig. 3 .

\footnotetext{
${ }^{1}$ http://www.ifd.mavt.ethz.ch/research/group_lk/projects/cochlear_mechanics
} 


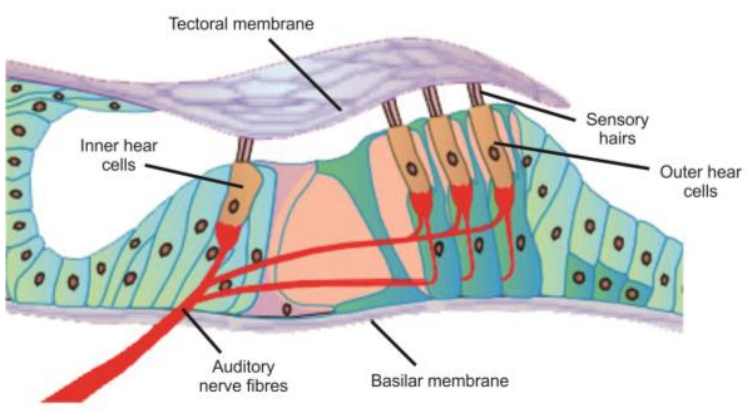

Fig. 3. - Organ of Corti

The most important parts of the organ of Corti are hair cells-outer and inner. Outer hair cells $(\mathrm{OHC})$ are responsible for the generation of current and feedback force which acts on the basilar membrane, amplifying the input signal in that manner. Inner hair cells (IHC) innervate nerves that carry information to the brain. The electro-mechanical model of the cochlea was analyzed as $1 \mathrm{D}$ problem with model in state space representation.

\section{Fundamental relations}

\subsection{Mechanical cochlea model}

Mechanical model of the cochlea consists of two chambers filled with fluid-scala vestibuli and scala tympani separated by basilar membrane. The third chamber, scala media, can be neglected in this type of analysis.

To investigate the mechanical behavior of the cochlea, the acoustic wave equation and Newtonian motion equation were used (Elliot et al (2013)). Acoustic wave equation has the form:

$$
\frac{\partial^{2} p}{\partial x_{i}^{2}}-\frac{1}{c^{2}} \frac{\partial^{2} p}{\partial t^{2}}=0
$$

In equation (1) $p$ stands for pressure of the fluid, $x_{i},(i=1,2,3)$ are spatial coordinates, $t$ is time and $c$ is speed of sound. Equation (1) can be written in the matrix form:

$$
\mathbf{Q} \ddot{\mathbf{p}}+\mathbf{H p}=\mathbf{0}
$$

where $\mathbf{Q}$ represents fluid mass matrix, and $\mathbf{H}$ is fluid stiffness matrix.

Solid elements were described with Newtonian dynamic equation:

$$
M \ddot{U}+\mathbf{C} \dot{U}+K U=F^{\text {ext }}
$$

where $\mathbf{M}, \mathbf{C}, \mathbf{K}$ are mass, damping and stiffness matrix, respectively, $\mathbf{U}$ is vector of displacement, and $\mathbf{F}^{\text {ext }}$ is vector of external forces.

In the modal analysis equation (3) can be rewritten in another form, since damping matrix can be presented as imaginary part of complex stiffness matrix,

$$
\mathbf{M} \ddot{\mathbf{U}}+\mathbf{K}(1+i \eta) \mathbf{U}=\mathbf{F}^{\text {ext }}
$$

In equation (4) $\eta$ is the hysteresis damping ratio. 
Combined together, equations (2) and (4) form a system:

$$
\left[\begin{array}{cc}
\mathbf{M} & \mathbf{0} \\
\rho_{f} \mathbf{R} & \mathbf{Q}
\end{array}\right]\left\{\begin{array}{l}
\ddot{\mathbf{U}} \\
\ddot{\mathbf{p}}
\end{array}\right\}+\left[\begin{array}{cc}
\mathbf{K}(1+i \eta) & -\mathbf{S} \\
\mathbf{0} & \mathbf{H}
\end{array}\right]\left\{\begin{array}{l}
\mathbf{U} \\
\mathbf{p}
\end{array}\right\}=\left[\begin{array}{l}
\mathbf{F} \\
\mathbf{q}
\end{array}\right]
$$

where $\mathbf{R}$ and $\mathbf{S}$ are coupling matrices ( $\mathbf{S}=\mathbf{R}^{T}$, (Zienkiewicz (1983)), and $\rho_{f}$ is density of the fluid inside the chambers.

Coupling condition used in this system is that normal pressure gradient of the fluid element in contact must be equal to normal acceleration of the solid element in the contact (Zienkiewicz (1983)), as it can be seen from equation (6),

$$
\mathbf{n} \cdot \nabla p=\rho \mathbf{n} \cdot \ddot{\mathbf{u}}
$$

If solutions for pressure and displacement are assumed in a sinusoidal form, then from equation (5) system will become system of linear equations, which can be easily solved in PAK solver:

$$
\left[\begin{array}{cc}
\mathbf{K}(1+i \eta)-\omega^{2} \mathbf{M} & -\mathbf{S} \\
-\rho_{f} \omega^{2} \mathbf{R} & \mathbf{H}-\omega^{2} \mathbf{Q}
\end{array}\right]\left\{\begin{array}{l}
\mathbf{A}_{U} \\
\mathbf{A}_{p}
\end{array}\right\}=\left[\begin{array}{l}
\mathbf{0} \\
\mathbf{q}
\end{array}\right]
$$

\subsection{Electro-mechanical cochlea model}

Electro - mechanical cochlea model includes generated current inside the organ of Corti. Organ of Corti is placed inside scala media, so model contains all three fluid chambers. Outer hair cells (OHC) play an important role in the electrical model of the cochlea. Most of the electrical models are presented by the state space models. The creation of the electrical model was based on the Lui and Neely work (Liu and Neely (2010)).

In contrast to the mechanical model, apart from the basilar membrane there are also oscillations of the $\mathrm{OHC}$ and motion of the reticular lamina, which separate the scala media and the scala tympani. Motion of the basilar membrane causes motion of the $\mathrm{OHC}$ and the reticular lamina:

$$
\xi_{b}=\xi_{r}+\xi_{o}
$$

where $\xi_{b}, \xi_{r}$ and $\xi_{o}$ are the displacement of the basilar membrane, displacement of reticular lamina and displacement of $\mathrm{OHC}$, respectively.

There are two membranes, solid parts - basilar membrane, and reticular lamina:

$$
\begin{aligned}
& m \ddot{\xi}_{b}+r \dot{\xi}_{b}+k \xi_{b}=-P \\
& M \ddot{\xi}_{o}+R \dot{\xi}_{o}+K \xi_{o}=f_{O H C}
\end{aligned}
$$

In equation (9) $m, r, k$ are mass, damping and stiffness matrices of basilar membrane per unit area, and $M, R, K$ are mass, damping and stiffness matrices of reticular lamina. $P$ is fluid pressure and $f_{O H C}$ is force which is generated due to the motion of $\mathrm{OHC}$ and which depends on transmembrane potential. OHC contraction is linearly proportional to charge accumulation $Q$ (the constant of proportionality is piezoelectric constant $T$ ),

$$
\xi_{o} T=Q
$$

Generated current is a function of transmembrane potential and charge accumulation: 


$$
i_{r}=C \frac{d V}{d t}+G V+\frac{d Q}{d t}
$$

On the other hand, the generated current is a function of motion of the reticular lamina:

$$
i_{r}=\alpha_{v} \dot{\xi}_{r}+\alpha_{d} \xi_{r}
$$

By combining equations (8) - (12), we obtained the model in the state space (equation (13)),

$$
\left\{\begin{array}{c}
\dot{\xi}_{r} \\
\dot{u}_{r} \\
\dot{u}_{o} \\
\dot{V} \\
\dot{Q}
\end{array}\right\}=\left[\begin{array}{ccccc}
0 & 1 & 0 & 0 & 0 \\
-\frac{k}{m} & -\frac{r}{m} & \frac{R}{M}-\frac{r}{m} & -\frac{1}{T M} & \frac{K T}{M}+\frac{1}{C_{g} T M}-\frac{k T}{m} \\
0 & 0 & -\frac{R}{M} & \frac{1}{T M} & -\frac{K T}{M}-\frac{1}{C_{g} T M} \\
\frac{\alpha_{d}}{C} & \frac{\alpha_{v}}{C} & -\frac{1}{C T} & -\frac{G}{C} & 0 \\
0 & 0 & \frac{1}{T} & 0 & 0
\end{array}\right]\left\{\begin{array}{c}
\xi_{r} \\
u_{r} \\
u_{o} \\
V \\
Q
\end{array}\right\}+\left\{\begin{array}{c}
0 \\
0 \\
-\frac{1}{m} \\
0 \\
0
\end{array}\right\} P(x)
$$

Fluid pressure is not state space variable. It is placed on the right hand side of the equation (13). According to Newtonian's second law and equation of continuity, together with the Neumann boundary conditions, pressure can be defined by the following:

$$
\begin{aligned}
& \frac{\partial^{2} p}{\partial x^{2}}=-\frac{\rho}{A} w \dot{u}_{r} \\
& \left.\frac{\partial p}{\partial x}\right|_{x=0}=-\rho \dot{v}_{s} \\
& \left.\frac{\partial p}{\partial x}\right|_{x=L}=-\frac{\rho}{A \cdot m_{h}} p
\end{aligned}
$$

In equation (14) $\dot{v}_{s}$ is acceleration at the stapes and it is assumed to be a sine function.

\section{Results}

\subsection{Results from mechanical cochlea model}

Mechanical cochlea model was tested firstly with frequency mapping along the cochlea. Basilar membrane of the cochlea has a capability to distinguish different input frequencies. For each input frequency in the range $16 \mathrm{~Hz}$ to $20 \mathrm{kHz}$, there is the characteristic place, where displacement of the basilar membrane reaches the peak.

Frequency mapping was established by Grennwood, based on the experimental measurements. It is the so called Greenwood function which can be used for validation of the model. Comparison of Grenwood function and results obtained by the finite element PAK solver, is presented in the Fig. 4. 


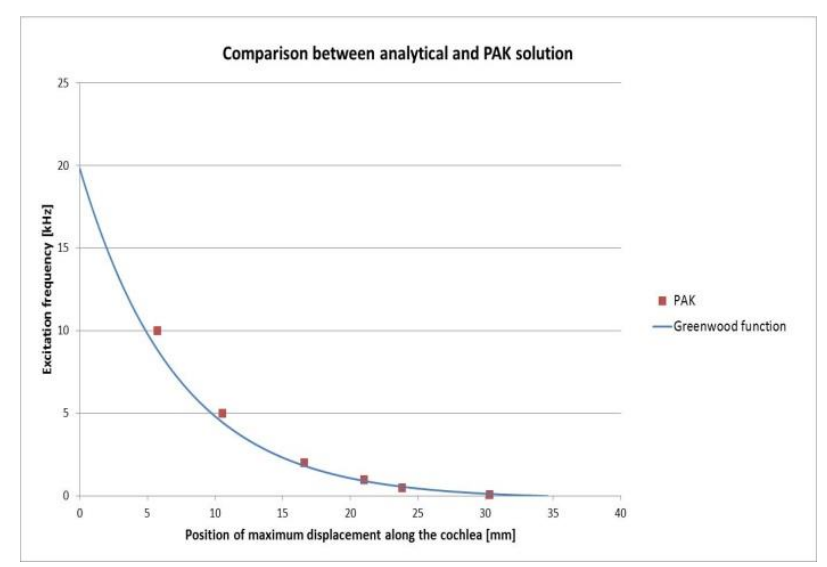

Fig. 4. - Frequency mapping obtained using PAK model and experimental data

It can be seen that results for mechanical cochlea model obtained using the PAK solver are in good agreement with Grenwood function, developed from experimental measurements (Fig. 4).

To obtain good frequency mapping with rectangular geometry of basilar membrane, material properties of the membrane need to be variable along the length. Young's modulous and damping were changed according to:

$$
\begin{aligned}
& E(x)=\frac{4 \pi^{2} f_{B}^{2}(x) A \rho\left(1-v^{2}\right)}{\beta^{4} I} \\
& \eta(x)=\frac{2 \omega \xi_{0} e^{x / l}}{\omega_{B}}
\end{aligned}
$$

where: $f_{B}(x)$ is frequency distribution along cochlear length, $A$ - cross-sectional area, $\rho$ density, $v$ - Poisson's ratio, $\beta$ - coefficient with a dimension of $m^{-1}$ which depends on boundary condition, $I$ - second moment of the cross-section, $\omega$ - circular frequency, $\xi_{0}$ basilar membrane damping ratio, $x$ - position along basilar membrane, $\omega_{B}$ - natural frequency at the base. Details about expressions (15) could be obtained in (Ni (2012)).

The results using the mechanical cochlea model were compared with results obtained with WKB method. The modal velocity magnitudes calculated by using PAK solver and by WKB method (Steele and Taber (1979)) are shown in Fig. 5.

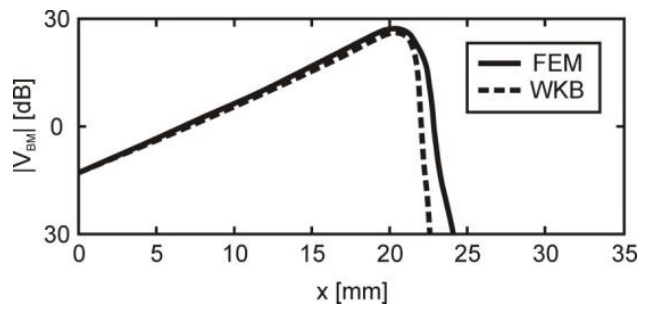

Fig. 5. - Modal velocity obtained using PAK model and the WKB method, for input frequency of $1 \mathrm{kHz}$ 
Agreement of the results shown in Fig. 5 serves as the validation of the mechanical cochlea model implemented in the PAK solver.

\subsection{Results obtained using the electro-mechanical cochlea model}

Displacement distribution of the reticular lamina was calculated by employing the electromechanical cochlea model. It was observed that for different excitation frequency displacement of reticular lamina reaches peak at different places along the length of the membrane. These positions of characteristic places are correspond to the Greenwood function.

The responses of reticular lamina for three different input frequencies: $500 \mathrm{~Hz}, 1 \mathrm{kHz}$ and 5 kHz, are plotted in Fig. 6.
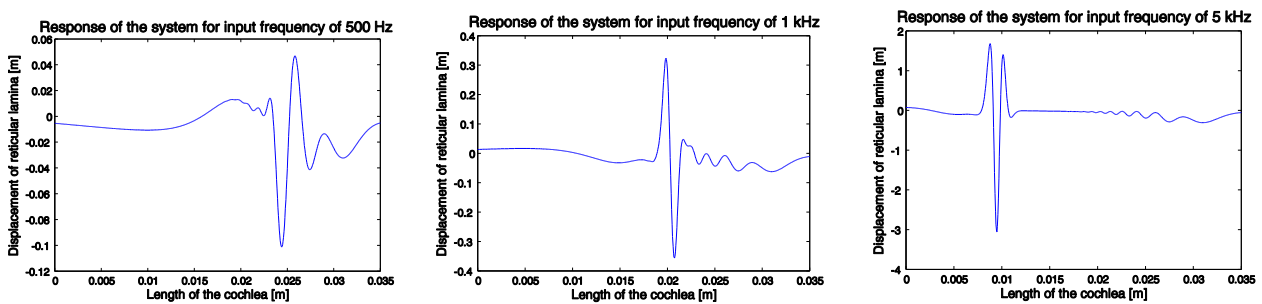

Fig. 6. - Reticular lamina displacements for input frequencies of $500 \mathrm{~Hz}, 1 \mathrm{kHz}$ and $5 \mathrm{kHz}$ obtained using electro-mechanical state-space model

Characteristic places are near the base (beginning of the membrane) at higher excitation frequencies, while at lower excitation frequencies characteristic places go toward apex side (the end of the membrane).

Displacement distribution obtained using the electro-mechanical model is sharper then displacements obtained using the mechanical model. The electrical part of the model works as an amplifier and produces faster and sharper response.

Results using the electro-mechanical and the mechanical model, developed from state-space model (equation 13), are presented in Fig. 7. Electrical variables are assumed to be zero. The input frequency was $1 \mathrm{kHz}$ and simulations were performed using 700 time steps and time step duration of $1 / 100000$ s.
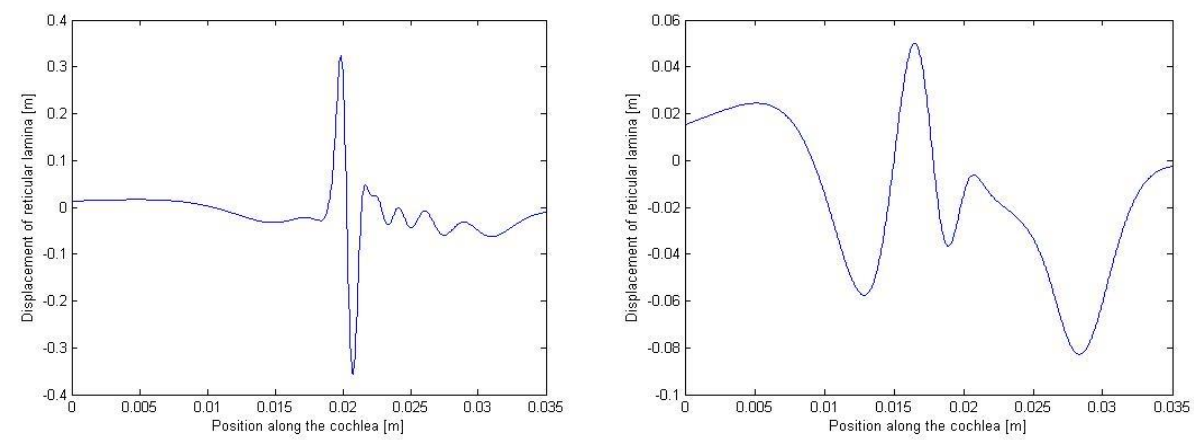

Fig. 7. - Displacement of reticular lamina from electro-mechanical (left) and mechanical (right) state-space model for input frequency of $1 \mathrm{kHz}$ 
It can be noticed that travelling wave travels slower when there are no electrical components in the model, and therefore mechanical model has slower response (Fig 7). Displacement is sharper for the electro-mechanical response and it is amplified. The magnitude of the displacement is larger for the electro-mechanical model than for mechanical cochlea model.

Displacement magnitude values depend on the level of the velocity at the stapes. Here it is only presented behavior of the electro-mechanical model, without comparison with experimental measurement because of the lack of data in the literature.

\title{
4. Conclusion
}

A 3D finite element mechanical cochlea model and 1D state-space electro-mechanical cochlea model show good matching with experimental measurements in terms of frequency mapping. Both models show the characteristic places for input frequencies which are in agreement with Greenwood function. The mechanical model results are compared with results obtained using WKB method in order to validate the model implemented in the PAK solver. By using the statespace electro-mechanical cochlea model, it was shown that the electrical part of the model has influence on the membrane response. Comparison of the models with and without electrical components showed the difference in amplification of the magnitude, different sharpness of the curves and difference in the time response. These models can be further generalized in order to include modeling of some realistic disturbances of the hearing system and to help clinicians in diagnosis and treatment of the diseases.

Acknowledgements. The authors acknowledge support of the Ministry of Education, Science and Technological Development of Serbia (grants III41007 and ON174028), and FP7 ICT SIFEM 600933 EU project.

\section{Извод}

\section{Механички и електро-механички бох модел кохлее}

\author{
M. Nikolic ${ }^{1,2}$, V. Isailovic ${ }^{1,2}$, D. Nikolic ${ }^{1,2}$, I. Saveljic ${ }^{1,2}$, Z. Milosevic ${ }^{1,2}$, M. Radovic ${ }^{1,2}$, \\ S.Semmelbauer ${ }^{3}$, F. Bohnke ${ }^{3}$ and N. Filipovic ${ }^{1,2^{*}}$ \\ 1Факултет инжињерских наука, Универзитет у Крагујевцу, Србија \\ obradovicm@kg.ac.rs \\ 2 Биоинжињеринг Р\&Д Центар Крагујевац, Крагујевац, Србија \\ 3 Department of Otorhinolaryngology, Technical University Munich, Munich, Germany \\ * Главни аутор
}

\section{Резиме}

Кохлеа је најважнији део органа слуха, због чињенице да прихвата звуке у облику вибрација и преводи ове вибрације у нервне импулсе унутар Кортијевог органа, који шаље информације о звуку до мозга. Функционисање компоненти кохлее и њихово понашање још увек није истражено у потпуности због њихове сложене структуре. Осим тога тешко је сакупити експерименталне податке за живе људске кохлее јер се налазе у веома неприступачном делу. До сада је утврђено да кохлеа ради као електро-механички систем и потребно је истражити и електрично и механичко понашање кохлее како би се побољшало лечење болести органа слуха. Овај рад представља механички модел несавијене кохлее 
направљен коришћењем 3Д осмочворних елемената, као и анализу електро-механичког $1 Д$ модела кохлее у простору стања. Резултати добијени из оба модела кохлее показују добро поређење са Грееншоод функцијом за одговарајуће понашање кохлее.

Кључне речи: кохлеа, метода коначних елемената, модел у простору стања

\section{References}

Elliott S J, Ni G, Mace B R, Lineton B (2013). A wave finite element analysis of the passive cochlea. The Journal of the Acoustical Society of America, vol. 133, issue 3, p. 1535

Kojic M, Slavkovic R, Grujovic N, Zivkovic Z, Filipovic N, (2009). PAK, Finite element software, BioIRC Kragujevac, University of Kragujevac, 34000 Kragujevac, Serbia.

Liu Y W and Neely S T (2010). Distortion product emissions from a cochlear model with nonlinear mechanoelectrical transduction in outer hair cells. Acoustical Society of America, 2010, DOI: $10.1121 / 1.3337233$.

Ni G (2012). Fluid coupling and waves in the cochlea - PhD thesis, University of Southampton, Faculty of engineering and the environment, Institute of sound and vibration research.

Nobili R, Mommano F and Ashmore J (1998). How well do we understand the cochlea?. TINS, 21(4), pp.159-166.

Steele C R (1987). Cochlear Mechanics. In Handbook of Bioengineering, R. Skalak and S. Chien, Eds., pp. 30.11-30.22, McGraw-Hill, New York.1987.

Steele C R and Taber L A (1979). Comparison of WKB calculations and experimental results for three-dimensional cochlear models. The Journal of the Acoustical Society of America, Volume 65, Issue 4, pp. 1007-1018.

Zienkiewicz O C (1983). The Finite Element Method: Third Edition, Published by McGraw-Hill Book Co. ( 1983-Third Edition ), New York, 1983, ISBN 10: 0070840725 / ISBN 13: 97800708407 